\title{
Groundwater quality monitoring in Denmark
}

\author{
Jens Stockmarr
}

As the drinking water supply in Denmark is totally based on groundwater, monitoring of the groundwater quality is extremely important to the Danish community. With more than $62 \%$ of the total land area under agricultural use the Danish Government has determined that the entire area is vulnerable to nitrate polution, and therefore the groundwater monitoring programme should cover the entire country.

The Danish groundwater monitoring programme comprises water supply well monitoring, the groundwater monitoring network and agricultural watershed monitoring (Figs 1,2 ) and is described on www.groundwater.dk. The programme is part of the National Action Programme for the Water Environment and Nature, NOVANA (Svendsen \& Norup 2004; Svendsen et al. 2005).

Groundwater quality monitoring is carried out on the basis of data from approximately 6200 public water supply wells. Furthermore, a detailed analytical programme is carried out on 1415 well screens from the monitoring network comprising 70 catchment areas, and on 100 shallow screens from the five agricultural watersheds (Svendsen et al. 2005). The detailed quality monitoring includes analyses for 97 chemical elements, comprising 26 main elements, 14 heavy metals, 23 organic micro-pollutants and 34 pesticides and metabolites.

\section{Nitrate}

The water supply wells generally have long screens and are intended to provide representative information on the distribution of the nitrate content in primary groundwater reservoirs. Data from water extraction wells are, however, biased since the wells are intended to ensure production of drinking water with nitrate concentrations below the maximum admissible concentration (MAC) of $50 \mathrm{mg}$ nitrate per litre.

The groundwater monitoring wells give a more accurate picture of the general nitrate pollution in the Danish groundwater. In 1998-2004, mean nitrate concentrations were above the MAC limit for drinking water in $16.9 \%$ of the wells, whereas about $60 \%$ had no nitrate $(<1 \mathrm{mg}$ nitrate per litre).

The spatial distribution of nitrate in the groundwater aquifers varies. West of the Weichselian glaciation borderline (Fig. 1), the outwash plains are dominated by upper, unconfined aquifers overlying deeper, confined Quaternary and Miocene sands. East of the glaciation borderline the sandy meltwater deposits and the pre-Quaternary limestone aquifers are generally covered by clayey till which reduces or prevents nitrate pollution (Fig. 3).

Over the past half century the use of fertilisers in farming has intensified dramatically (Fig. 4). Groundwater from the monitoring screens has been dated using the CFC (chlorofluorocarbon) content (GEUS 2004), and demonstrates that the highest nitrate values reflect the increase in the use of fertilisers (Fig. 4). Continued monitoring will show whether the decrease in the use of fertilisers during the last decade will result in a decrease in the nitrate content, or whether the increasing use of manure will maintain high nitrate levels. Preliminary data suggest, however, that since 1979 farmers have adapted their spreading practice for fertilisers and manure such that nitrate pollution is now following a declining trend.

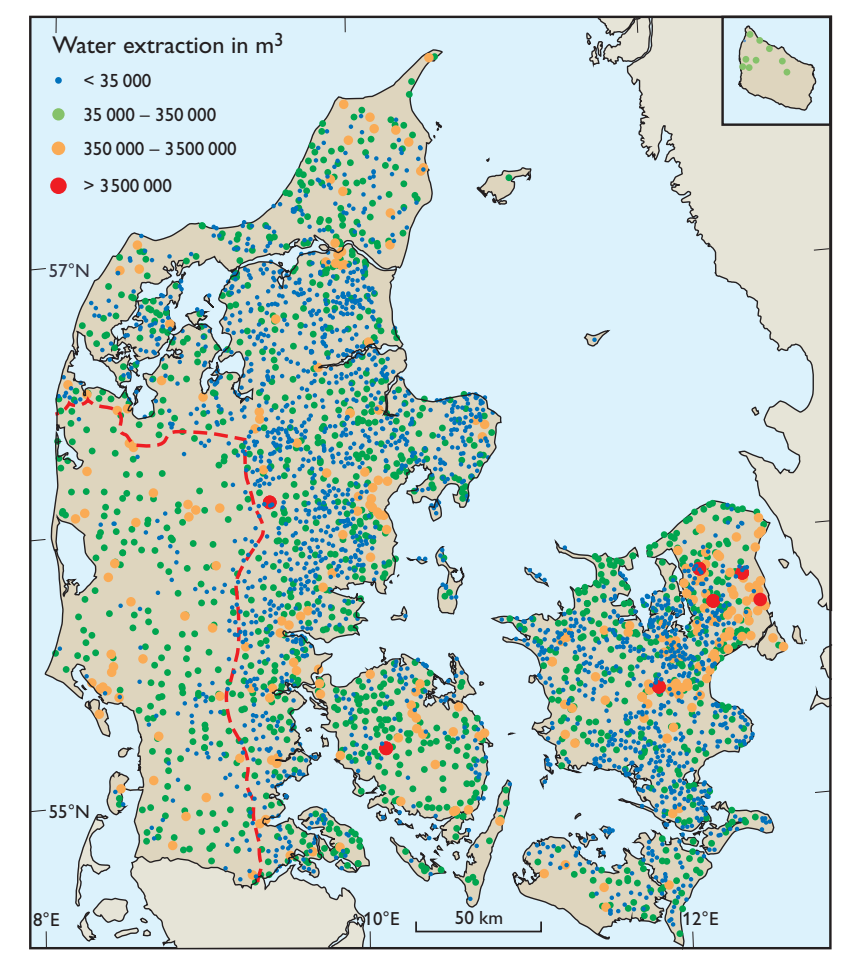

Fig. 1. Extraction of water for domestic consumption from approximately 3000 Danish public waterworks in 2001. All waterworks (except one) are based on groundwater extraction. Red dashed line indicates the position of the Weichselian glaciation borderline. The island of Bornholm is shown in the inset map. Modified from Fraters et al. (2005). 


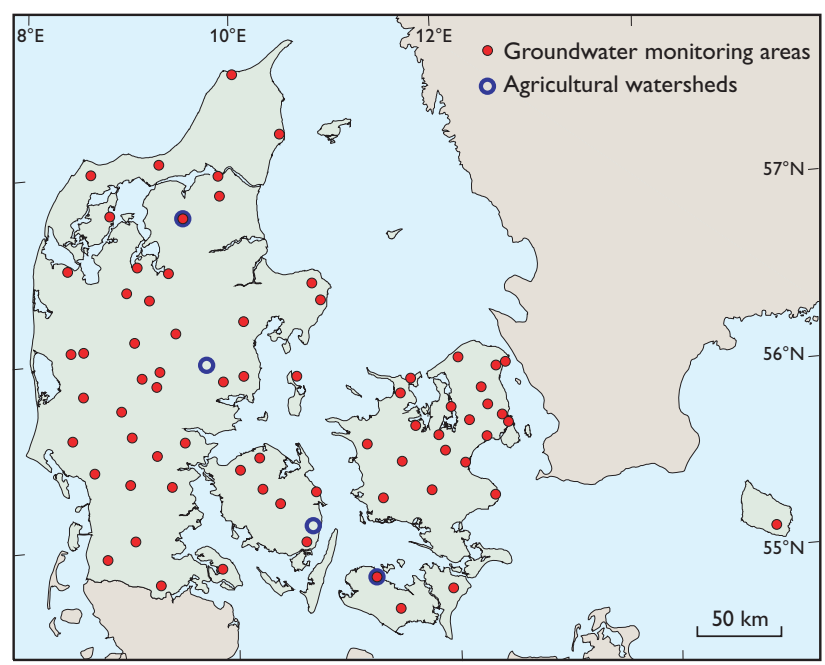

Fig. 2. Network of Danish national groundwater monitoring areas (catchments) and selected agricultural watersheds covered by the extended monitoring programme. From Stockmarr \& Nyegaard (2004).

\section{Nickel, arsenic and other inorganic trace elements}

The most widespread impact from inorganic trace elements is due to nickel derived from oxidation of pyrite, bravoite and other heavy metal bearing sulphides (Fig. 5). Massive dissolution of sulphides occurs in areas where large-scale extraction of groundwater has caused lowering of the groundwater table, followed by an influx of oxic groundwater. During dissolution, some of the nickel is adsorbed by contemporaneously precipitated manganese oxide. The trapped nickel is, however, released when the groundwater table rises again, since this leads to reducing conditions and dissolution of the manganese oxides.

Implementation in 2001 of the EU Drinking Water Directive in Danish legislation has led to increased concern with respect to arsenic, for which the MAC value was decreased from 50 to $5 \mu \mathrm{g} / \mathrm{l}$. Nine per cent of the monitoring well

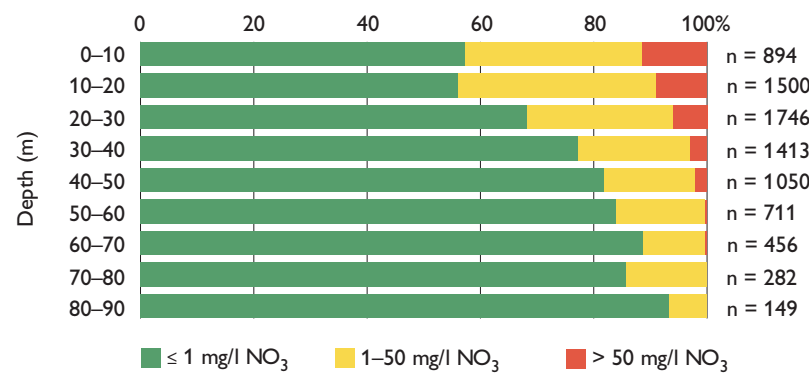

Fig. 3. Distribution of nitrate versus depth to well screen in groundwater monitoring and water supply wells. The data cover the period 19982003 and are grouped into three classes according to mean nitrate. From GEUS (2004). screens in the groundwater monitoring programme currently exceed $5 \mu \mathrm{g} / \mathrm{l}$ in all samples, while $14 \%$ exceed $5 \mu \mathrm{g} / \mathrm{l}$ in at least one sample (Fig. 6). The distribution of arsenic is to a large degree controlled by redox conditions, as the solubility of arsenic is about ten times higher in reducing environments compared to oxidising conditions. High arsenic concentrations are mainly found in aquifers underlying clayey sediments.

As a result of seven years of groundwater monitoring, the background levels of the 23 inorganic trace elements analysed are well known and are illustrated by the cumulative curves in Fig. 7. Most curves show a regular distribution, e.g. strontium $(\mathrm{Sr})$ and mercury $(\mathrm{Hg})$, indicating little or no pollution, whereas the skewed curves for aluminium (Al) and nickel (Ni) reflect pollution.

\section{Pesticides and metabolites}

Analytical results from the water supply wells, the groundwater monitoring areas and the agricultural watersheds differ markedly (Fig. 8). Only agricultural pesticides were detected in water samples collected from young groundwater in the agricultural watersheds, whereas in water samples collected in the groundwater monitoring network other pesticides, such as those used in consolidated areas like urban areas, roads or farmyards have also been found. Pesticides and their metabolites are found in more than $25 \%$ of all wells (Table 1; GEUS 2004).

Table 1. Pesticides and metabolites in Danish groundwater

\begin{tabular}{|c|c|c|c|c|c|}
\hline \multirow{2}{*}{$\begin{array}{l}\text { Pesticides and } \\
\text { metabolites } \\
1998-2003\end{array}$} & \multirow[t]{2}{*}{$\begin{array}{l}\text { Number of } \\
\text { analysed screens }\end{array}$} & \multicolumn{2}{|c|}{$\begin{array}{l}\text { Screens with } \\
\text { findings }\end{array}$} & \multicolumn{2}{|c|}{$\begin{array}{c}\text { Findings } \geq \\
0.1 \mu \mathrm{g} / \mathrm{(MAC})\end{array}$} \\
\hline & & Number & $\%$ & Number & $\%$ \\
\hline Monitoring network & 1020 & 437 & 42.8 & 153 & 15.0 \\
\hline Agricultural watersheds & 75 & 52 & 69.3 & 19 & 25.3 \\
\hline Water supply wells & 5515 & 1443 & 26.2 & 355 & 6.4 \\
\hline
\end{tabular}

MAC: maximum admissible concentration. From GEUS (2004).

The most frequently found pesticide group consists of triazines and their metabolites. These compounds are commonly found in both farming and urban areas. In the agricultural watersheds the triazines and their metabolites make up about half of all recorded pesticides and metabolites.

In water supply wells the analytical data indicate a very high frequency of 2,6-dichlorobenzamide (BAM) findings. Twenty-five per cent of the wells contain BAM, and 10\% have concentrations above the MAC value of $0.1 \mathrm{mg} / \mathrm{l}$. BAM is a metabolite from dichlobenil and chlorothiamide that were commonly used prior to 1997 as a total herbicide in urban areas, along roads and in farmyards. 
Fig. 4. Nitrate content versus CFC age of groundwater. The annual use of nitrogen fertilisers is shown for comparison.

Groundwater data from the anoxic zone are corrected on the basis of sulphate content. Slightly modified from GEUS (2004).

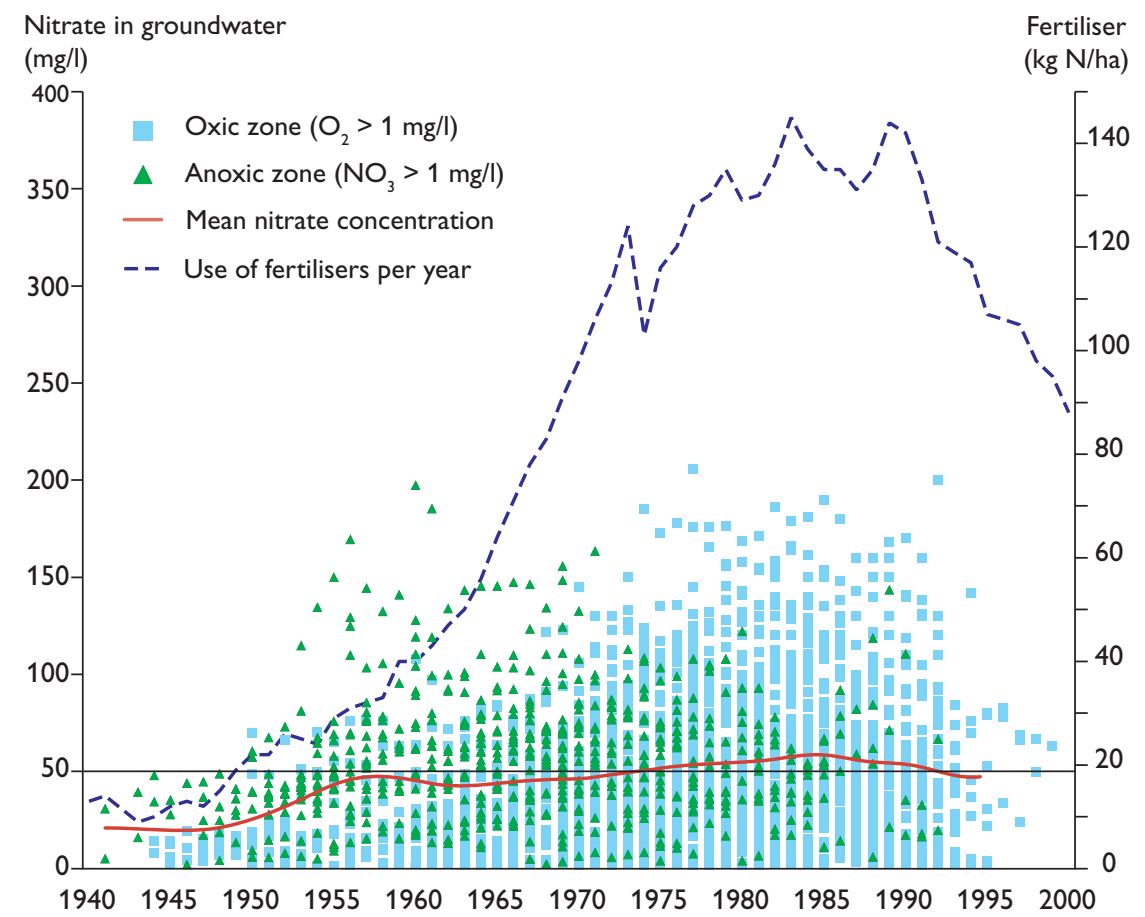

The monitoring network demonstrates high detection rates for pesticides in the upper 40-50 m of wells tested, and a lower number of findings with increasing depth (Fig. 8).

\section{Pollution in shallow groundwater}

Drinking water from 628 dug wells and shallow drilled wells used for single private supply and minor partnership supplies (less than nine families) was investigated in a research project focusing on the youngest groundwater (Brüsch et al. 2004).

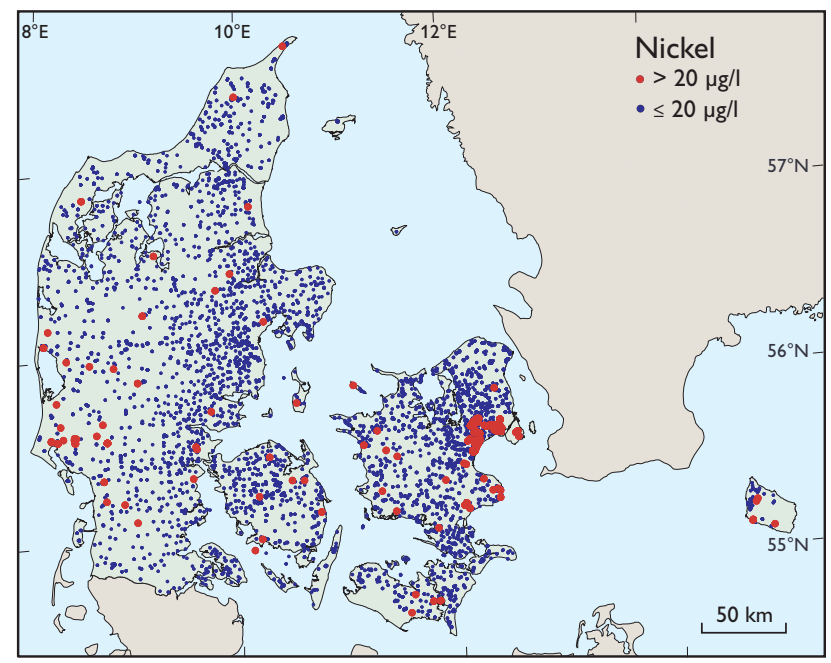

Fig. 5. Occurrence of nickel in Danish water supply wells, 1998-2003. Slightly modified from GEUS (2004).
In $35 \%$ of the investigated wells, pesticides and their metabolites were recorded with values above the MAC value for drinking water $(0.1 \mathrm{mg}$ per litre), whereas $11 \%$ of wells had more than ten times the MAC value.

The research project showed that nitrate pollution in $22 \%$ of the wells was above $50 \mathrm{mg}$ per litre. The MAC level for bacteria was exceeded in $48 \%$ of the wells whereas $31 \%$ contained coliforme bacteria. In total, $68 \%$ of the private supply and minor partnership supply wells delivered undrinkable water.

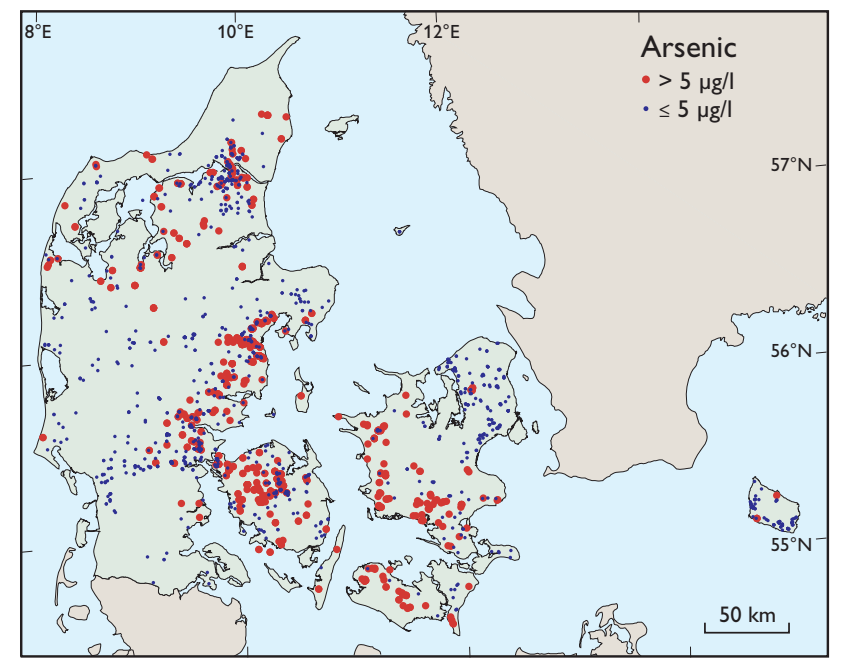

Fig. 6. Occurrence of arsenic in Danish water supply wells, 1998-2003. Slightly modified from GEUS (2004). 


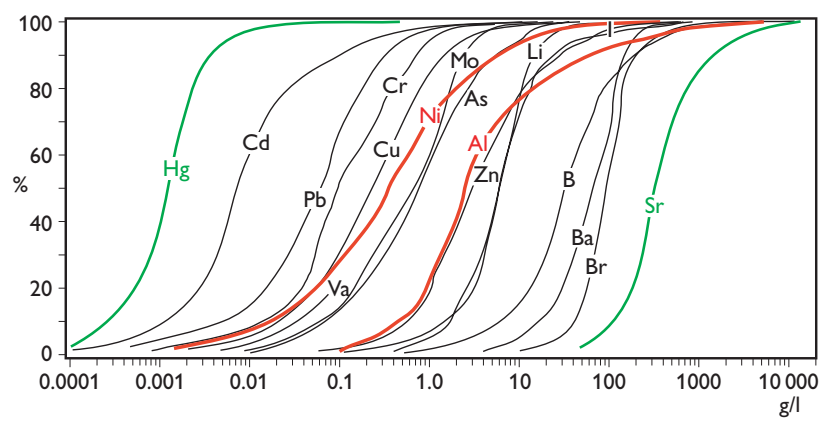

Fig. 7. Inorganic trace elements found in Danish monitoring wells from 1993 to 1999. The skewness of the distribution pattern in the curves for nickel $(\mathrm{Ni})$ and aluminium $(\mathrm{Al})$ reflects pollution. Regular distributions, as e.g. for $\mathrm{Hg}$ and $\mathrm{Sr}$, indicate little or no pollution. Slightly modified from Stockmarr et al. (2002).

\section{Conclusions}

During the last two decades many water supply wells have been closed due to pollution; initially this was a result of nitrate pollution, and subsequently also to pesticide pollution. Nickel contamination has also closed some wells, and it is feared that arsenic will cause closure of more wells. In some cases the water supply companies have extended their production wells to greater depth instead of closing them, but often this is not a viable solution.

Due to government policy that drinking-water production should be based on pure groundwater requiring only simple treatment (aeration and iron removal), only few water supply companies have had permission to install advanced water treatment for removal of pesticides or nickel. However, more and more water supplies are expected to need advanced water treatment in the future.

Nitrate pollution is still the most serious problem because intensive agricultural practices cause leakage of nitrate into groundwater and surface water. While a series of action plans have been introduced to reduce nitrate pollution, much of the young groundwater and most of the surface water in Denmark are seriously polluted by nitrate.

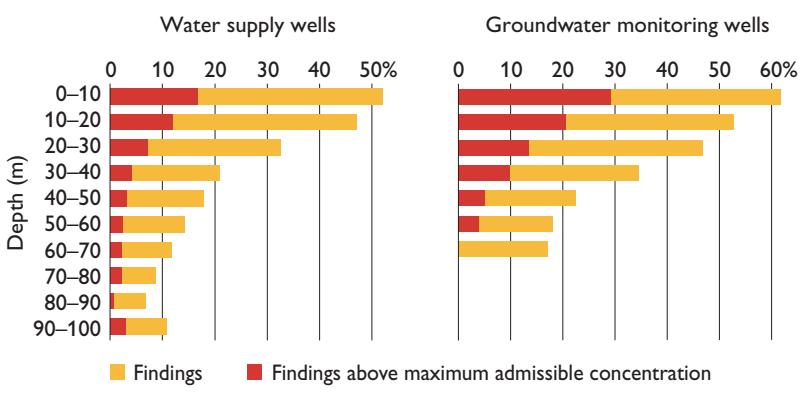

Fig. 8. Occurrence of pesticides and metabolites in water supply and groundwater monitoring wells versus depth to top of well screen, 19982003 as percentage of number of screens investigated. Slightly modified from GEUS (2004).

\section{References}

Brüsch, W., Stockmarr, J., Kelstrup, N., von Platen-Hallermund, F. \& Rosenberg, P. 2004: Pesticidforurenet vand i små vandforsyningsanlæg. Danmarks og Grønlands Geologiske Undersøgelse Rapport 2004/9, 85 pp.

Fraters, B., Kovar, K., Willems, W.J., Stockmarr, J. \& Grant, R. (eds) 2005: Monitoring effectiveness of the EU Nitrates Directive Action Programmes. Results of the international $\mathrm{MonNO}_{3}$ workshop, The Hague, the Netherlands, 11-12 June, 2003. RIVM Report 680100002/2005, $290 \mathrm{pp}$.

GEUS 2004: Grundvandsovervågning 1998-2003, 48 pp. København: Danmarks og Grønlands Geologiske Undersøgelse.

Stockmarr, J. \& Nyegaard, P. 2004: Nitrate in Danish groundwater. In: Razowska-Jaworek, L. \& Sadurski, A. (eds): Nitrates in groundwater. International Association of Hydrogeologists, Hydrogeology, Selected Papers 5, 187-199.

Stockmarr, J., Nyegaard, P., Larsen, C.L., Felding, G. \& Brüsch, W. 2002: Groundwater quality monitoring in Denmark. Third International Conference on Water Resources and Environment Research (ICWRER), Dresden, Germany 22-26 July, 2002, Proceedings, 165-169.

Svendsen, L. \& Norup, B. (eds) 2004: NOVANA. Det nationale program for overvågning af vandmiljøet og naturen. Programbeskrivelse - del 1. Danmarks Miljøundersøgelser, Faglig rapport fra DMU 495, 45 pp. Svendsen, L.M., van der Bijl, L., Boutrup, S. \& Norup, B. (eds) 2005: NOVANA. Det nationale program for overvågning af vandmiljøet og naturen. Programbeskrivelse - del 2. Danmarks Miljøundersøgelser, Faglig rapport fra DMU 508, 128 pp.

\section{Author's address}

Geological Survey of Denmark and Greenland, Øster Voldgade 10, DK-1350 Copenhagen K, Denmark. E-mail: sto@geus.dk 